\title{
KOMPETENSI DOSEN, GAMBARAN UMUM ALUMNI DAN PERKEMBANGANNYA
}

\author{
Zainal Abidin ${ }^{1}$, Alamsyah $^{2}$, Baiq Nurul Suryawati ${ }^{3}$ \\ ${ }^{l}$ Fakultas Ekonomi dan Bisnis Unram, zainalabidin@gmail.com \\ ${ }^{2}$ Fakultas Ekonomi dan Bisnis Unram, alamsyah@gmail.com \\ ${ }^{3}$ Fakultas Ekonomi dan Bisnis Unram, nurul.suryawati@unram.ac.id
}

\begin{tabular}{ll|lll}
\hline Article history & \multicolumn{1}{l}{} \\
\hline Dikirim tanggal & $: 11 / 12 / 2019$ & Diterima tanggal & $:$ & $8 / 09 / 2020$ \\
Revisi pertama tanggal & $: 8 / 09 / 2020$ & Tersedia online tanggal & $:$ & $29 / 9 / 2020$ \\
\hline
\end{tabular}

\begin{abstract}
ABSTRAK
Penelitian ini bertujuan untuk mengetahui perkembangan kompetensi dosen jurusan manajemen, lama masa tunggu para alumni lulusan tahun 2017 dalam memasuki dunia kerja, kesesuaian latar belakang pendidikan alumni tahun 2017 dengan pekerjaan yang ditekuni sekarang, kemampuan dalam menciptakan lapangan pekerjaan sendiri atau hanya menunggu dan mencari pekerjaan, kompetensi lulusan dalam pekerjaannya, dan kontribusi jurusan Manajemen FEB Unram dalam membentuk kompetensi lulusan tersebut. Hasil penelitian adalah kompetensi Dosen FEB Jurusan Manajemen ditinjau dari tiga aspek: 1) Persentase Dosen yang mendapat tunjangan sertifikasi, dari dosen FEB jurusan manajemen sebanyak $96,67 \%$ telah mendapat tunjangan serifikaasi dosen, sisany $3,33 \%$ belum mendapat sertifikasi dosen, ini berarti bahwa sebagian besar telah memenuhi syarat sebagai dosen yang berkompeten. 2) Dari sisi perilaku kerja dosen FEB Manajemen Unram, sebanyak 95,08 persen berperilaku sangat baik, dan sisanya berperilaku baik. 3) Jabatan Fungsional Dosen FEB Manajemen Unram, Jabatan Guru Besar 1 orang, jabatan Lektor Kepala 19 orang, jabatan Lektor 32 orang, jabatan Asisten Ahli 9 orang. Pendidikan Dosen FEB sudah menenuhi ketentuan yang sudah ada, dengan kondisi 38,33 persen S-3, sisanya 61,67 persen S-2. Untuk masa tunggu para alumni Manajemen FEB dalam memasuki dunia kerja, 23,46\% mendapatkan pekerjaan sebelum lulus dengan masa tunggu rata-rata,5,8 bln dan $76,54 \%$ mendapatkan pekerjaan sesudah lulus dengan masa tunggu rata-rata 4,58 bulan. Selain itu, sebanyak $19,8 \%$ responden menyatakan bahwa antara latar belakang pendidikan dengan pekerjaan pertama yang ditekuni sangat erat, 30,9 persen menyatakan erat, $21 \%$ menyatakan cukup erat, 9,9 persen meyatakan kurang erat dan sisanya 4,9 persen menyatakan tidak sama sekali.
\end{abstract}

Keywords: Kompetensi dosen dan alumni jurusan manajemen

\section{ABSTRACT}

This study aims to determine the development of competence in management department lecturers, the long waiting period for graduates of 2017 alumni in entering the workforce, the suitability of 2017 alumni's educational background with current occupations, the ability to create their own jobs or just waiting and looking for work, graduate competencies in his work, and contributions from the Management Department of Economics and Business Faculty in shaping the competencies of the graduates. The results of the study are the competencies of the Faculty of Management FEB Lecturers in terms of three aspects: 1) The percentage of lecturers who received certification allowances, FEB lecturers majoring in management as many $96.67 \%$ had received lecturer certification, the remaining 3 , $33 \%$ have not yet received lecturer certification, this means that most have qualified as competent lecturers. 2) In terms of the work behavior of Management FEB lecturers, 95.08 percent behaved very well, and the rest behaved well. 3) a kind Functional Position of Management Department Lecturer. 1 person in Professor, 19 people on Associate Professor, 32 people Position of Lector, and Position of Assistant 9 people. Level of Education FEB lecturers has fulfilled the existing provisions, with the condition that $38.33 \%$ have master degree, the remaining $61.67 \%, 34$ people have master degree. For the waiting period of FEB Management alumni in entering the workforce and got jobs before graduating, $23.46 \%$ with an average waiting period, 5.8 months before graduating, while $76.54 \%$ got jobs after graduation with an average waiting period of 4.58 months. In addition, as many as $19.8 \%$ of respondents stated that between their educational background and the first occupation that were occupied very 
closely, 30.9\% stated closely, 21\% stated quite closely, 9.9 percent stated less closely, and the remaining 4.9 percent stated not at all.

Keywords: Competence of lecturers and alumni majoring in management.

\section{PENDAHULUAN}

\section{Latar Belakang}

Dalam rangka menunjang pelaksanaan program penyelarasan pendidikan dengan dunia kerja, dan menyiapkan lulusan perguruan tinggi (PT) untuk bersaing di pasar kerja yang makin kompetitif, Perguruan Tinggi (PT) harus memfasilitasi upaya peningkatan kebekerjaan (employability) lulusannya. Fakultas Ekonomi dan Bisnis Universitas Mataram sebagai salah satu lembaga pendidikan tinggi negeri di Nusa Tenggara Barat (NTB) tidak boleh ketinggalan dalam memajukan dunia pendidikan melalui peningkatan kinerja akademik terutama dalam menyelaraskan kurikulum yang ada dengan berbagai stakeholders sehingga dapat melahirkan lulusan yang berkualitas secara akademis dan terampil dalam menjalankan pekerjaan didunia kerja.

Tuntutan akan kompetensi para pendidik (dosen) dan lulusan merupakan faktor pendorong untuk melakukan perbaikan dan pembenahan dalam rencana strategis kedepan seperti proses pelaksanaan akademis, serta kelengkapan sarana dan prasarana yang dibutuhkan dalam dunia pendidikan. Fakultas Ekonomi dan Bisnis (FEB) Universitas Mataram sebagai lembaga yang mengelola lembaga pendidikan tinggi memiliki Visi, yaitu "Menjadi lembaga pendidikan tinggi berbasis riset berdaya saing internasional tahun 2025". Untuk merealisasikan visi tersebut FEB menyelenggarakan misi, yaitu ; a) Melaksanakan proses pendidikan tinggi berstandar mutu nasional dan internasional yang berbasis riset yang kuat, b) melaksanakan kegiatan riset berstandar mutu nasional dan internasional, c) melaksanakan pengabdian kepada masyarakat yang didasari pada hasil riset, dalam rangka memberikan kontribusi untuk memecahkan berbagai persoalan yang timbul di masyarakat, mendorong pertumbuhan ekonomi, dan membangun sosial serta budaya masyarakt Indonesia, d) membangun jaringan kerjasama yang luas dengan berbagai pihak instansi pemerintah dan swasta, di dalam dan luar negeri, dan e) melaksanakan tata kelola aset, keuangan dan administrasi yang memenuhi standar tata kelola Universitas yang baik, efisien, efektif, transparan dan akuntable (good university governance),

Secara kelembagaan setiap lembaga pendidikan dituntut oleh stakeholders tentang kiprah nyata mencerdaskan generasi bangsa dalam wujud melahirkan lulusan yang berkualitas secara akademis dan terampil dalam melaksanakan tugas yang dipercayakan kepadanya. Untuk merealisasikan tuntutan tersebut, lembaga pendidikan dituntut untuk terus mereorganisasi dirinya dan meningkatkan kualitas layanan pendidikan kepada masyarakat.

Jurusan Manajemen regular pagi pada tahun 2017 melalui satu kali wisuda telah meluluskan alumni sebanyak 210 orang, penelusuran secara menyeluruh dan berkelanjutan terhadap para pendidik dan para lulusannya perlu dilakukan. Penelusuran yang dilakukan selama ini bersifat terbatas dalam bentuk sampel yang kecil. Oleh karenanya perlu dilakukan penelusuran secara menyeluruh tentang kompetensi dosen dan Keberadaan alumni setelah lulus.

\section{Tujuan}

Berdasarkan latar belakang di atas maka tujuan dari kajian ini adalah adalah sebagai berikut: 
1. Untuk mengetahui perkembangan kompetensi dosen jurusan Manajemen FEB Unram tahun 2019

2. Untuk Menganalisis masa tunggu para alumni lulusan tahun 2017 dalam memasuki dunia kerja.

3. Untuk mengetahui kesesuaian latar belakang pendidikan alumni tahun 2017 dengan pekerjaan yang ditekuni sekarang.

4. Untuk Mengetahui kemampuan alumni FEB Universitas Mataram tahun 2017 dalam menciptakan lapangan pekerjaan sendiri.

5. Untuk Mengetahui kompetensi alumni FEB Universitas Mataram lulusan tahun 2017 dalam pekerjaannya.

6. Untuk mengetahui kontribusi jurusan Manajemen FEB Unram dalam membentuk kompetensi lulusan tersebut.

\section{Kompetensi}

\section{KAJIAN PUSTAKA}

\section{Pengertian Kompetensi}

Menurut Kamus Kompetensi LOMA (1998), kompetensi didefinisikan sebagai aspek-aspek pribadi dari seorang pekerja yang memungkinkan dia untuk mencapai kinerja yang superior. Aspek-aspek pribadi ini termasuk sifat, motif-motif, sistem nilai, sikap, pengetahuan, dan ketrampilan. Kompetensi-kompetensi akan mengarahkan tingkah laku. Sedangkan tingkah laku akan menghasilkan kinerja.

Berdasarkan definisi tersebut maka dapat disimpulkan bahwa tidak semua aspekaspek pribadi dari seseorang pekerja itu merupakan kompetensi.

\section{Kompetensi Dosen}

Dosen adalah sebuah profesi yang memerlukan kualifikasi dan kompetensi dosen tertentu. Seperti dengan Dokter dan profesi yang lain, kualifikasi dan kompetensi Dosen ditentukan dan diatur oleh Undang - Undang. Secara rinci diatur dalam UndangUndang Nomor 14 tahun 2005, tentang Guru dan Dosen. Dalam UU tersebut dijelaskan bahwa Dosen wajib memiliki kualifikasi akademik, kompetensi, sertifikat pendidik, sehat jasmani dan rohani, dan memenuhi kualifikasi lain yang dipersyaratkan satuan pendidikan tinggi tempat bertugas, serta memiliki kemampuan untuk mewujudkan tujuan pendidikan.

Kualifikasi Akademik Dosen yang dimaksud adalah minimal melalui pendidikan tinggi program pascasarjana yang terakreditasi sesuai dengan bidang ilmu keahlian. JIka dahulu lulusan sarjana bisa menjadi dosen, setelah keluarnya UU tersebut mewajibkan seorang dosen bergelar magister untuk mengajar program diploma dan sarjana. Dan lulusan program doktor utnuk mengajar program pascasarjana.

Sertifikat pendidik untuk Dosen diberikan setelah memenuhi beberapa syarat antara lain: a) memiliki pengalaman kerja sebagai pendidik pada perguruan tinggi sekurang-kurangnya dua tahun, b) memiliki jabatan akademik sekurang-kurangnya asisten ahli, c) lulus sertifikasi yang dilakukan oleh perguruan tinggi yang menyelenggarakan program pengadaan tenaga kependidikan pada perguruan tinggi yang ditetapkan oleh Pemerintah.

Sertifikasi pendidik untuk dosen dilaksanakan melalui uji kompetensi dosen untuk memperoleh sertifikat pendidik. Uji kompetensi sebagaimana dimaksud dilakukan dalam bentuk penilaian portofolio. Untuk pengadaan tenaga pengajar Dosen, hanya bisa dilakukan oleh perguruan tinggi yang telah terakreditasi yang ditunjuk oleh pemerintah dan segala peraturan mengenai srtifikasi dosen dan penetapan perguruan 
tinggi terakreditasi penyelenggara program pengadaan tenaga pendidik diatur dalam Peraturan Pemerintah. Untuk memenuhi itu seorang dosen harus memiliki 4 (empat) kompetensi, yaitu:

1. Kompetensi Kepribadian

2. Kompetensi Profesional (Keilmuan dan Keterampilan)

3. Kompetensi Pedagogik

4. Kompetensi Sosial

\section{Kompetensi Kepribadian}

1. Bertindak sesuai dengan norma agama, hukum, dan sosial-budaya masyarakat Indonesia

2. Tampil sebagai pribadi yang jujur, berakhlak mulia, dan teladan bagi mahasiswa dan masyarakat

3. Tampil sebagai pribadi yang mantap, stabil, dewasa, arif, dan berwibawa

4. Menunjukkan etos kerja, tanggungjawab yang tinggi, rasa percaya diri, dan rasa bangga sebagai pendidik

5. Menjunjung tinggi kode etik profesi dosen

\section{Kompetensi Profesional}

1. Menguasai \& mengembangkan materi, struktur, konsep dan pola pikir keilmuan yang mendukung pengembangan mata kuliah yang diampu

2. Menguasai standar kompetensi, kompetensi dasar, dan indikator matakuliah yg diampu

3. Mengembangkan materi pembelajaran matakuliah yang diampu secara kreatif dan terus menerus

4. Mengembangkan keprofesionalan secara berke-lanjutan dengan melakukan tindakan refleksi

5. Memanfaatkan teknologi informasi dan komunikasi untuk mengembangkan potensi diri

\section{Kompetensi Pedagogik}

1. Menguasai karakteristik mahasiswa dari aspek fisik, spiritual, sosial-kultural, emosional, moral dan intelektual

2. Menguasai teori belajar dan prinsip-prinsip pembelajaran yang mendidik

3. Mengembangkan kurikulum yang terkait dengan matakuliah yang diampu

4. Menyelenggarakan pembelajaran yang kreatif, edukatif, dan menyenangkan

5. Memanfaatkan teknologi informasi dan komunikasi untuk kepentingan pembelajaran

6. Memfasilitasi pengembangan potensi mahasiswa agar dapat mengaktualisasi berbagai potensi yang dimiliki

7. Berkomunikasi secara efektif, empatik, dan santun dengan mahasiswa

8. Menyelenggarakan penilaian atau evaluasi proses dan hasil pembelajaran

9. Memanfaatkan hasil penilaian atau evaluasi untuk kepentingan pembelajaran

10. Melakukan tindakan reflektif guna peningkatan kualitas pembelajaran

\section{Kompetensi Sosial}

1. Bersikap inklusif dan bertindak secara objektif dalam berbagai aspek kehidupan

2. Tidak bersikap diskriminatif karena pertimbangan jenis kelamin, agama, ras/etnis, kondisi fisik, latar belakang keluarga, dan status sosial ekonomi 
3. Berkomunikasi secara efektif, simpatik-empatik, dan santun dengan sesama dosen, tenaga kependidikan, pemangku kepentingan, dan masyarakat

4. Beradaptasi di tempat/lingkungan bertugas yang memiliki keragaman sosial budaya

5. Berkomunikasi dengan komunitas profesi sendiri dan profesi lain secara lisan dan tulisan atau bentuk lain

\section{Model Kompetensi}

Model kompetensi didefinisikan sebagai suatu rangkaian kompetensi yang penting bagi kinerja yang superior dari sebuah pekerjaan atau sekelompok pekerjaan. Model kompetensi ini memberikan sebuah peta yang membantu seseorang memahami cara terbaik mencapai keberhasilan dalam pekerjaan atau memahami cara mengatasi suatu situasi tertentu (LOMA,s Competency Dictionary, 1998).

Menurut Kamus Kompetensi LOMA (1998) aplikasi dari model kompetensi pada sistem Manajemen Sumber Daya Manusia muncul pada area-area berikut:

1. Staffing. Strategi-strategi rekrutmen dan tes-tes yang digunakan untuk seleksi didasarkan atas kompetensi-kompetesi kritikal dari pekerjaan

2. Evaluasi Kinerja. Penilaian kinerja dari pekerja didasarkan atas kompetensikompetensi pekerja diberikan kompensasi yang dikaitkan dengan target -target yang penting dari organisasi

3. Pelatihan. Program-program pelatihan dirancang untuk menjembatani kesenjangan antara kompetensi yang dimiliki pekerja dan kompetensi yang diharapkan dimiliki pekerja

4. Pengembangan. Para pekerja pertama kali diukur untuk mengenali kesenjangan kompetensinya; kemudian mereka dibimbing untuk membuat rencana-rencana pengambangan untuk menutupi kesenjangan yang ada.

5. Reward \& Recognition. Para pekerja diberikan kompensasi untuk prestasi-prestasi dan tingkah laku-tingkah laku yang mencerminkan tingkat ketrampilan mereka pada kompetensi-kompetensi kunci.

Hal tersebut di atas sejalan dengan pendapat dari Michael Amstrong dalam Handbook of Human Resources Management Practice (2001) yang mengemukakan bahwa penerapan kompetensi dalam Manajemen SDM dilakukan dalam proses rekrutmen dan seleksi, assessment centres, manajemen kinerja, pengembangan SDM, dan manajemen imbal jasa.

\section{Teori Pasar Kerja}

Pasar kerja adalah seluruh aktivitas pelaku-pelaku ekonomi yang mempertemukan pencari kerja dan kesempatan kerja. Pelaku-pelaku tersebut terdiri dari: (1) pengusaha yang membutuhkan pekerja, dan (2) pencari kerja yang membutuhkan pekerjaan.

Proses interaksi keduanya membutuhkan waktu yang lama karena baik pencari kerja maupun kesempatan kerja tidak homogen dan informasi mengenai keduanya sangat terbatas. Pencari kerja ingin memperoleh pekerjaan dengan kondisi yang paling baik dan pengusaha ingin mencari pekerja yang paling cocok untuk mengisi lowongan. Di dalam pasar kerja terjadi proses penempatan atau hubungan kerja melalui penyediaan dan permintaan tenaga kerja. Proses ini lebih lanjut dijelaskan dalam teori penawaran dan permintaan tenaga kerja.

Penawaran suatu komoditi adalah hubungan antara harga dan kuantitas. Sehubungan dengan tenaga kerja, penawaran adalah hubungan antara tingkat upah dengan jumlah tenaga kerja yang siap disediakan oleh para pemilik tenaga kerja. 
Namun, dalam menawarkan tenaganya, seorang pekerja dihadapkan pada kendala kelangkaan waktu. Secara rasional seorang pekerja harus membuat pilihan dalam pengguanan waktunya antara bekerja dan waktu istirahat (leisure).

Permintaan terhadap tenaga kerja merupakan permintaan tak langsung. Maksudnya, tenaga kerja dipekerjakan oleh perusahaan dengan tujuan untuk digunakan dalam menghasilkan barang-barang yang akan mereka jual (Sukirno, 2000). Dengan kata lain, pertambahan permintaan pengusaha terhadap tenaga kerja tergantung dari pertambahan permintaan masyarakat terhadap barang yang diproduksinya. Oleh karena itu permintaan akan tenaga kerja merupakan permintaan turunan.

Fungsi permintaan tenaga kerja biasanya didasarkan kepada teori neoklasik, dimana pada ekonomi pasar diasumsikan bahwa seorang pengusaha tidak dapat mempengaruhi harga (price taker). Dalam hal memaksimalkan laba, pengusaha hanya dapat mengatur berapa jumlah karyawan yang dapat dipekerjakan (Simanjuntak, 1985).

\title{
Teori Kualitas Pelayanan
}

Kualitas merupakan suatu kondisi dinamis yang berpengaruh dengan produk, jasa, manusia, proses dan lingkungan yang memenuhi atau melebihi harapan (Tjiptono, 2001). Sehingga definisi kualitas pelayanan dapat diartikan sebagai upaya pemenuhan kebutuhan dan keinginan konsumen serta ketepatan penyampaiannya dalam mengimbangi harapan konsumen (Tjiptono, 2007).

Menurut Kotler (2002:83) definisi pelayanan adalah setiap tindakan atau kegiatan yang dapat ditawarkan oleh suatu pihak kepada pihak lain, yang pada dasarnya tidak berwujud dan tidak mengakibatkan kepemilikan apapun. Produksinya dapat dikaitkan atau tidak dikaitkan pada satu produk fisik. Pelayanan merupakan perilaku produsen dalam rangka memenuhi kebutuhan dan keinginan konsumen demi tercapainya kepuasan pada konsumen itu sendiri. Kotler juga mengatakan bahwa perilaku tersebut dapat terjadi pada saat, sebelum dan sesudah terjadinya transaksi.

\begin{abstract}
Alumni
Alumni adalah kata benda jamak dalam bahasa Inggris yang berarti lulusan pria dari suatu sekolah. Bentuk tunggalnya adalah alumnus. Sedangkan alumna juga kata benda jamak dalam bahasa Inggris yang berarti lulusan wanita dari suatu sekolah. Bentuk tunggalnya adalah alumnae (John M. Echols dan Hasan Shadily, 1995:25-26). Dalam studi penulusuran ini akan menggunakan istilah bahasa Inggris yang sudah diserap ke dalam bahasa Indonesia, yaitu alumni tanpa membedakan jenis kelamin dari lulusan tersebut.

Penelusuran adalah kegiatan mencari informasi tentang hal yang belum diketahui dengan pasti. Informasi yang hendak digali dalam penelitian ini adalah tentang keberadaan alumni setelah meninggalkan bangku kuliah. Keberadaan alumni tersebut mencakup: (1) masa tunggu alumni semenjak lulus sampai dengan mendapatkan pekerjaan pertama, (2) tempat bekerja alumni, (3) perkembangan karir alumni, (4) cara alumni mengembangkan kemampuan akademik, (5) kepuasan stakeholders atas kinerja alumni, (6) kepuasan alumni atas kinerja program studi, (7) harapan stakeholders atas kinerja program studi, dan (8) harapan alumni atas kinerja program studi.

Kurikulum adalah seperangkat mata pelajaran yang diajarkan pada lembaga pendidikan atau seperangkat mata kuliah mengenai bidang keahlian khusus yang disajikan secara saling terkait satu sama lain (KBBI, 2002:617). Sampai saat ini belum ada kesatuan pendapat mengenai pengertian kurikulum. Pandangan lama menyatakan
\end{abstract}


bahwa kurikulum merupakan seperangkat mata pelajaran dan materi pelajaran yang harus diajarkan oleh guru kepada peserta didik. (Moh. Ansyar dan Nurtain 1993). Sedangkan Oliver (dalam Brown dan Brown, 1985: 24) memberikan tiga macam definisi kurikulum yakni: (a) All the experiences a child as under the guidance of school, (b) all the courses or subject which the school offers, dan (c) the systematic arrangement of subject matter within a course offered by a school.

Said Hamid Hasan (1988) melihat kurikulum ada empat sudut pandang, yakni kurikulum sebagai ide, rencana tertulis, kegiatan dan hasil belajar. Sementara Hilda Taba berpendapat bahwa rumusan kurikulum yang terlalu luas justru akan mengaburkan pengertian kurikulum sendiri. Secara singkat, Hilda Taba (dalam Nasution, 1993:10) merumuskan kurikulum sebagai "a plan for learning" yakni sesuatu yang direncanakan untuk dipelajari oleh siswa.

Pengertian kurikulum dalam Undang-Undang No 20 Tahun 2003 tentang Sistem Pendidikan Nasional menyatakan bahwa kurikulum merupakan seperangkat dan pengaturan mengenai isi, tujuan dan bahan pelajaran serta cara yang digunakan sebagai pedoman penyelenggaraan kegiatan pembelajaran untuk mencapai tujuan pendidikan tertentu.

\section{Jenis Penelitian}

\section{METODE PENELITIAN}

Kegiatan Tracer Study dilakukan menggunakan desain penelitian Diskriptif, yaitu mendiskripsikan data sesuai dengan variabel yang dibutuhkan dalam penelitian. Data variabel tersebut diperoleh dengan melibatkan semua populasi yaitu semua lulusan/alumni yang diwisuda pada tahun 2017. Kemudian proses analisis dilakukan sesuai dengan koesioner yang telah diisi dan dikembalikan oleh alumni. Alur kegiatan Tracer Study dapat dilihat pada diagram berikut.

\section{Jenis Dan Sumber Data \\ Jenis Data} kualitatif

Jenis data yang digunakan dalam penelitian ini adalah data kuantitatif dan data

\section{Sumber Data}

Adapun sumber data yang digunakan dalam penelitian ini adalah:

1. Data primer, yaitu data yang diperoleh secara langsung dari responden di lokasi penelitian, seperti identitas responden.

2. Data sekunder, yaitu data yang diperoleh dari dokumen jurusan, fakultas dan bahan bacaan atau literatur yang berkaitan dengan.

\section{Penentuan Subyek dan Informan Penelitian}

Subyek penelitian adalah semua dosen Jurusan Manajemen FEB dan alumni Jurusan Manajemen Fakultas Ekonomi dan Bisnis Universitas Mataram, tahun lulusan 2017 yang tersebar di seluruh wilayah Nusantara.

\section{Teknik Pengumpulan Data}

Berkaitan dengan sumber data penelitian, peneliti menggunakan beberapa teknik pengumpulan data, yaitu:
a) Angket,
b) Wawancara,
c) Dokumentasi. 


\section{Langkah-langkah Penelitian}

1. Tahap Pra-lapangan

Pada tahap ini peneliti mengadakan survey pendahuluan. Selama proses ini peneliti mengadakan penjajagan lapangan (field study) terhadap subyek penelitian dan menyusun rancangan penelitian.

2. Tahap Pekerjaan Lapangan

Dalam tahap ini peneliti memasuki dan memahami setting penelitian dalam rangka pengumpulan data. Langkah-langkahnya sebagai berikut:

a) Membuat rute penelusuran berdasarkan sebaran daerah asal alumni.

b) Melaksanakan penelusuran terhadap alumni yang terpilih secara acak dan lulus sampling.

c) Wawacara dilakukan terhadap alumni dan stakeholders.

d) Kuisioner diberikan kepada alumni dan stakeholders.

e) Menyusun data lapangan sebagai bahan laporan.

f) Evaluasi dan refleksi.

3. Tahap Analisis Data

Peneliti melakukan serangkaian proses analisa data kuantitatif berupa angket sampai pada interpretasi data yang sudah diperoleh sebelumnya. Selain itu peneliti juga menempuh proses trianggulasi data.

4. Tahap Evaluasi dan Pelaporan. Tahap ini merupakan tahap terakhir dan dilaksanakan setelah penelitian diuji.

\section{Analisis Data}

Teknik analisis data yang diperlukan dalam penelitian ini adalah sebagai berikut:

1. Reduksi data (Data Reduction), Proses ini dilaksanakan dengan

2. memilah data dari catatan tertulis di lapangan.

3. Penyajian data (Display Data), Data yang telah direduksi, disajikan

4. dalam laporan sistematis, mudah dibaca dan difahami, baik secara

5. keseluruhan maupun per bagian,

6. Diskripsi data dengan bantuan statistic diskriptif

7. Pengambilan Kesimpulan (Verification), data yang telah diproses kemudian ditarik kesimpulan dengan menggunakan metode induktif, yaitu proses penyimpulan dari hal-hal yang sifatnya khusus ke hal-hal yang sifatnya umum agar diperoleh kesimpulan yang obyektif.

\section{HASIL DAN PEMBAHASAN}

\section{Kompetensi Dosen Manajemen Fak. Ekonomi dan Bisnis Unram Sertifikasi Dosen}

Persentase Dosen yang Mendapat Tunjangan Sertifikasi, dari 60 orang dosen FEB jurusan manajemen sebanyak 58 orang (95 persen) telah mendapat tunjangan serifikaasi dosen, sisanya belum mendapat sertifikasi dosen, ini berarti bahwa sebagian besar telah memenuhi syarat sebagai dosen yang berkompeten. 


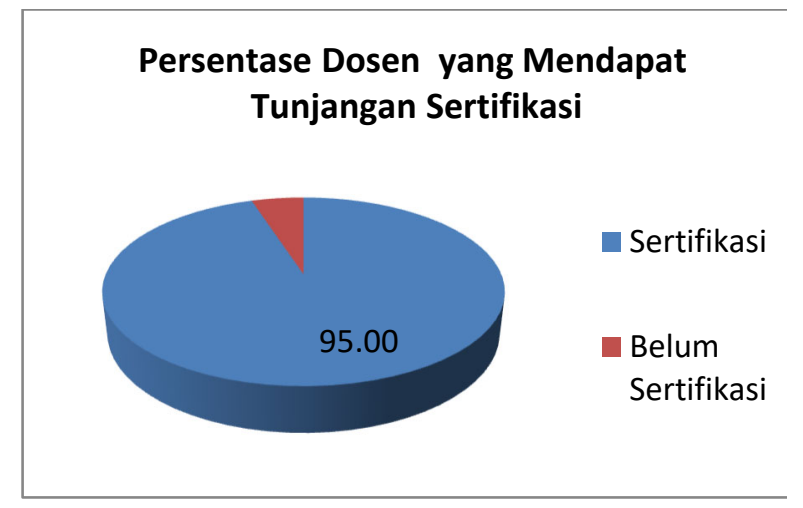

Tabel 1. Tabel Sertifikasi Dosen FEB

Manajemen Unram 2018/2019

Gambar 1, Dosen Tersertifikasi

\section{Kompetensi Perilaku Kerja}

Untuk mengetahui kompetensi dosen dari sisi tindakan dan perilaku kerja dalam menyelesaikan suatu persoalan dapat dilihat dari sikanya terhadap:

1. Bertindak sesuai dengan norma agama, hukum, dan sosial-budaya masyarakat Indonesia

2. Tampil sebagai pribadi yang jujur, berakhlak mulia, dan teladan bagi mahasiswa dan masyarakat

3. Tampil sebagai pribadi yang mantap, stabil, dewasa, arif, dan berwibawa

4. Menunjukkan etos kerja, tanggungjawab yang tinggi, rasa percaya diri, dan rasa bangga sebagai pendidik

5. Menjunjung tinggi kode etik profesi dosen

Penilaian terhadap perilaku kerja dosen dilakukan oleh ketua prodi dengan skala angka dari 10 sampai 100 dengan kriteria sebagai berikut:

Tabel 2. Skala Penilaian Perilaku Dosen FEB Jurusan Manajemen Unram

\begin{tabular}{|c|c|}
\hline NILAI ANGKA & SEBUTAN \\
\hline $91-100$ & Sangat Baik \\
\hline $76-90$ & Baik \\
\hline $61-75$ & Cukup \\
\hline $51-60$ & Kurang \\
\hline 50 KE BAWAH & Buruk \\
\hline
\end{tabular}

Sumber data: data sekunder.

Berarti ada 5 rentang skala yang digunakan untuk mengetahui kinerja penilaian perilaku dosen dalam Tabel 2. Berdasarkan kriteria penilaian diatas Dari sisi perilaku kerja dosen FEB Manajemen Unram, Nilai maksismum, minimum dan rata-ratanya dapat dilihat pada Tabel 3. berikut:

Tabel 3. Penilaian Perilaku Dosen FEB Jurusan Manajemen Unram 2018-2019

\begin{tabular}{|l|c|c|c|}
\hline \multicolumn{1}{|c|}{ KETERANGAN : } & $\mathbf{2 0 1 8}$ & $\mathbf{2 0 1 9}$ & Perubahan \\
\hline 1. Orientasi Pelayanan & 82.52 & 82.02 & -0.6059 \\
\hline 2. Integritas & 82.7 & 82.00 & -0.8464 \\
\hline 3. Komitmen & 90 & 88.33 & -1.8556 \\
\hline
\end{tabular}

Pengaruh Brand Ambassador Terhadap Citra Merek dan Keputusan ... $\mid 181$ 


\begin{tabular}{|l|c|c|c|}
\hline \multicolumn{1}{|c|}{ KETERANGAN : } & $\mathbf{2 0 1 8}$ & $\mathbf{2 0 1 9}$ & Perubahan \\
\hline 4. Disiplin & 82.91 & 81.95 & -1.1579 \\
\hline 5. Kerjasama & 82.76 & 81.86 & -1.0875 \\
\hline 6. Kepemimpinan & 81.61 & 79.40 & -2.708 \\
\hline
\end{tabular}

Sumber : data primer diolah

Dari kriteria penilaian diatas maka alokasi dosen dari sisi perilaku kerja dosen FEB Manajemen Unram, sebanyak 58 orang atau 95,08 persen berperilaku sangat baik, dan sisanya berperilaku baik, selengkapnya dapat dilihat pada tabel berikut:

\begin{tabular}{|c|c|c|c|c|c|}
\hline \multicolumn{3}{|c|}{ Persentase } & \multicolumn{3}{|c|}{$\begin{array}{l}\text { Tabel 4. Perilaku Dosen Fakultas } \\
\text { Ekonomi dan Bisnis Universitas } \\
\text { Mataram tahun } 2018\end{array}$} \\
\hline \multirow[t]{7}{*}{13.79} & \multirow{7}{*}{86.21} & \multirow{7}{*}{$\begin{array}{l}\text { Baik } \\
\text { Sangat Baik }\end{array}$} & $\begin{array}{c}\text { Nilai Perilaku } \\
\text { Kerja }\end{array}$ & $\begin{array}{l}\text { Jumlah } \\
\text { (orang) }\end{array}$ & $\begin{array}{c}\text { Persentase } \\
(\%)\end{array}$ \\
\hline & & & Sangat Baik & 8 & 16 \\
\hline & & & Baik & 50 & 86 \\
\hline & & & Cukup & - & - \\
\hline & & & Kurang & - & - \\
\hline & & & Buruk & - & - \\
\hline & & & & 58 & 100 \\
\hline
\end{tabular}

Gambar 2, Perilaku 2018 (data sekunder diolah)

\begin{tabular}{|c|c|c|c|c|}
\hline \multirow[t]{8}{*}{ Persen } & \multirow{8}{*}{$\begin{array}{l}\text { Baik } \\
\text { Cukup } \\
\text { Sangat baik }\end{array}$} & \multicolumn{3}{|c|}{$\begin{array}{l}\text { Tabel 5. Perilaku Kerja Dosen } \\
\text { Fakultas Ekonomi dan Bisnis } \\
\text { Universitas Mataram } 2019\end{array}$} \\
\hline & & Kriteria & $\begin{array}{l}\text { Jumlah } \\
\text { (orang) }\end{array}$ & $\begin{array}{c}\text { Persen } \\
(\%)\end{array}$ \\
\hline & & Sangat baik & 4 & 7.02 \\
\hline & & Baik & 52 & 91.23 \\
\hline & & Cukup & 1 & 1.75 \\
\hline & & Kurang & - & - \\
\hline & & Buruk & - & - \\
\hline & & & 57 & 100 \\
\hline
\end{tabular}

Gambar 3, Perilaku 2019 (data sekunder diolah)

Data pada grafik dan tabel 5 diatas menunjukkan bahwa perilaku kerja dosen Jurusan Manajemen FEB Unramtahun 2019 mengalami penurunan dibanding tahun 2018, perilaku sangat baik mengalami penurunan dari 16 persen menjadi 7,02 persen seangkan yang berperilaku baik mengalami kenaikan dari 50 orang atau 86 persen menjadi 52 orang atau meningkat menjadi 91,23 persen dibanding dengan tahun 2018.

\section{Kompetensi Pendidikan /Profesional}

Kompetensi dosen dari sisi tingkat pendidikan disamping pendidikan formal juga terhadap kemampuan dalam mengembangkan kemampuannya, hal tersebut dapat dilihat

182 | Pengaruh Brand Ambassador Terhadap Citra Merek dan Keputusan ... 
dari kemampuannya terhadap:

1. Menguasai \& mengembangkan materi, struktur, konsep dan pola pikir keilmuan yang mendukung pengembangan mata kuliah yang diampu

2. Menguasai standar kompetensi dasar, dan indikator matakuliah yg diampu.

3. Mengembangkan materi pembelajaran matakuliah yang diampu secara kreatif dan terus menerus

4. Mengembangkan keprofesionalan secara berke-lanjutan dengan melakukan tindakan refleksi

5. Memanfaatkan teknologi informasi \& komunikasi untuk mengembangkan potensi diri

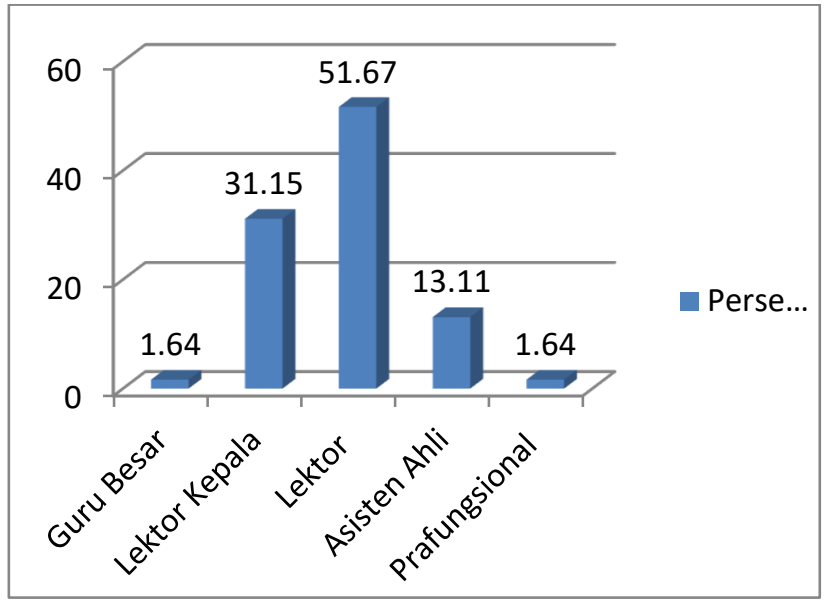

Gambar 4, Jabatan Fungsional Dosen

Jabatan Fungsional Dosen FEB Manajemen Unram tahun 2019 belum mengalami perubahan disbanding tahun sebelumnya, Jabatan Guru Besar 1 orang (1.64 persen), jabatan Lektor Kepala 19 orang (31.15 persen), jabatan Lektor 32 orang (52.46 persen), jabatan Asisten Ahli 8 orang (13.11 persen), dan jabatan Prafungsional 1 orang (1.64 persen).

Tabel 6, Tingkat Pendidikan Dosen Jurusan Manajemen FEB Unram tahun 2018

\begin{tabular}{|l|r|c|}
\hline Tingkat Pendidikan & \multicolumn{1}{|c|}{$\begin{array}{l}\text { Jumlah } \\
\text { (orang) }\end{array}$} & Persentase \\
\hline S-3 Doktor & 25 & 41.67 \\
\hline S-2 Magister & 31 & 51.66 \\
\hline Pendidikan S-3 & 4 & 6.66 \\
\hline Jumlah & 60 & 100.00 \\
\hline
\end{tabular}

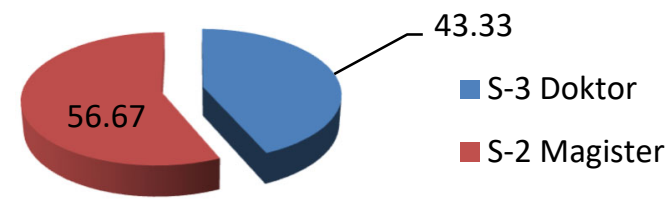

Sumber : data primer diolah

Gambar 5, Tingkat Pendidikan 2018 
Tabel 7.Tingkat Pendidikan Dosen Jurusan Manajemen FEB Unram tahun 2019

\begin{tabular}{|l|r|c}
\hline \multicolumn{1}{|c|}{ Tingkat Pendidikan } & \multicolumn{1}{c|}{$\begin{array}{l}\text { Jumlah } \\
\text { (orang) }\end{array}$} & Persentase \\
\hline S-3 Doktor & 26 & 43.33 \\
\hline S-2 Magister & 30 & 50,00 \\
\hline Pendidikan S-3 & 4 & 6.67 \\
\hline Jumlah & 60 & 100.00 \\
\hline
\end{tabular}

Gambar 6. Tingkat Pendidikan 2019

\section{Persentase}

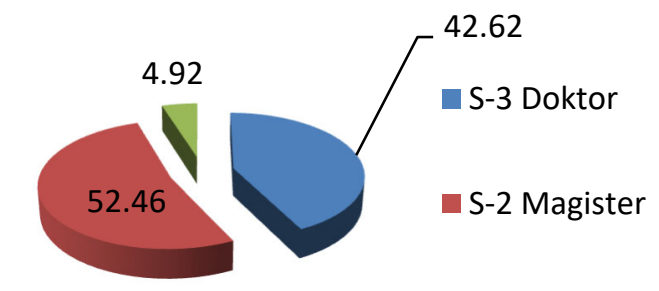

Pendidikan S-3

Tingkat Pendidikan Dosen FEB tahun 2019 sudah memenuhi ketentuan yang ada dan mengalami peningkatan dibanding tahun sebelumnya, dengan kondisi 41 persen (25 orang) sudah berpendidikan S-3, sisanya 58,33 persen (35 orang) berpendidikan S-2 pada tahun 2018 meningkat menjadi 26 orang 42,62 persen berpendidikan S-3, dan pendidikan S-3 sebanyak 3 orang.

\section{Evaluasi Mahasiswa Atas Kinerja Dosen Dalam Perkuliahan}

Dalam melaksamakam kegiata proses belajar mengajar, dosen dituntut mengusai metode dan tehnik mengajar, untuk menilai kemampuan dosen tersebut dilakukan penilaian oleh mahasiswa yang meliputi:

1. Menguasai karakteristik mahasiswa dari aspek fisik, spiritual, sosial-kultural, emosional, moral dan intelektual

2. Menguasai teori belajar dan prinsip-prinsip pembelajaran yang mendidik

3. Mengembangkan kurikulum yang terkait dengan matakuliah yang diampu

4. Menyelenggarakan pembelajaran yang kreatif, edukatif, dan menyenangkan

5. Memanfaatkan teknologi informasi dan komunikasi untuk kepentingan pembelajaran

6. Memfasilitasi pengembangan potensi mahasiswa agar dapat mengaktualisasi berbagai potensi yang dimiliki

7. Berkomunikasi secara efektif, empatik, dan santun dengan mahasiswa

8. Menyelenggarakan penilaian atau evaluasi proses dan hasil pembelajaran

9. Memanfaatkan hasil penilaian atau evaluasi untuk kepentingan pembelajaran

10. Melakukan tindakan reflektif guna peningkatan kualitas pembelajaran

Penilaian kinerja dosen dalam perkuliahan dilakukan dengan penyebaran kuesioner untuk mengetahui respon/pendapat mahasiswa selama perkuliahan yang dilakukan. Penilaian dilakukan terhadap 10 (sepuluh) unsur, seperti tampak dalam tabel berikut:

Tabel 8. Unsur Penilaian Terhadap Kinerja Dosen Dalam Perkuliahan

\begin{tabular}{|c|l|}
\hline NO & \multicolumn{1}{|c|}{ UNSUR PENILAIAN } \\
\hline$(1)$ & \multicolumn{1}{|c|}{$(2)$} \\
\hline 1 & $\begin{array}{l}\text { Untuk Mata Kuliah yang diampu, Tim Dosen yang masuk pada } \\
\text { pertemuan awal menyampaikan Rencana Perkuliahan } \\
\text { Semester (RPS)/Silabus/SAP) pada awal perkuliahan }\end{array}$ \\
\hline 2 & Ketaatan terhadap RPS/Silabus/SAP \\
\hline 3 & Ketepatan waktu mulai dan mengakhiri perkuliahan \\
\hline
\end{tabular}




\begin{tabular}{|c|l|}
\hline 4 & Frekuensi Kehadiran dosen \\
\hline 5 & Kemampuan dalam menjelaskan materi perkuliahan \\
\hline 6 & Pengkayaan dosen atas materi yang diberikan \\
\hline 7 & $\begin{array}{l}\text { Respon dosen terhadap pertanyaan/pernyataan mahasiswa berkaitan dengan materi } \\
\text { kuliah }\end{array}$ \\
\hline 8 & $\begin{array}{l}\text { Kemampuan dosen memotivasi dan menginspirasi mahasiswa untuk belajar mandiri } \\
\text { dan mengembangkan diri lebih lanjut }\end{array}$ \\
\hline 9 & Dosen memberikan umpan balik terhadap hasil kerja Mahasiswa \\
\hline 10 & Pemanfaatan teknologi informasi dan komunikasi dalam proses perkuliahan \\
\hline
\end{tabular}

Sumber : Data Sekunder.

Tabel 8 diatas menunjukkan sepuluh unsur penilaian terhadap kinerja dosen dalam perkuliahan akan diukur dengan menggunakan skala penilaian $1-5$ dimana nilai 5 = sangat baik; nilai $4=$ baik, nilai $3=$ cukup, nilai $2=$ kurang, nilai $1=$ sangat kurang.

Hasil evaluasi kinerja dosen dalam perkuliahan pada semester Gasal TA 2017/2018 ditampilkan dalam tabel berikut ini:

Berdasarkan Tabel 8 di atas, mahasiswa telah melakukan evaluasi terhadap kinerja dosen pada setiap mata kuliah yang diampu. Teknik penilaian ini dilakukan dengan menyebarkan kuesioner kepada beberapa mahasiswa yang dipilih secara acak. Kepada mereka sebelum mulai mengisi kuesioner, mahasiswa diberikan penjelasan mengenai tujuan pengisian kuesioner. Mahasiswa diberikan kebebasan penuh untuk menilai kinerja dosen tanpa adanya arahan untuk memberikan nilai-nilai tertentu. Hal ini dimaksudkan untuk menjaga kehandalan dalam memperoleh hasil penilaian. Kuesioner disebar pada waktu pertemuan terakhir dosen dengan mahasiswa dalam memberikan kuliah atau ketika ujian tengah semester dan akhir semester berlangsung.

Tabel 9. Hasil Penilaian Mahasiswa Terhadap Kinerja Dosen FEB Manajemen dalam Perkuliahan tahun 2018

\begin{tabular}{|l|c|c|}
\hline \multicolumn{1}{|c|}{ Kategori } & Jumlah Kelas & Persentase \\
\hline 1. Sangat kurang & - & - \\
\hline 2. Kurang & - & - \\
\hline 3. Cukup & 1 & 1 \\
\hline 4. Baik & 66 & 92 \\
\hline 5. Sangat baik & 5 & 7 \\
\hline Jumlah Kelas & 72 & 100 \\
\hline
\end{tabular}

Sumber data Primer diolah 2019

Hasil Penilaian Mahasiswa Terhadap Kinerja Mengajar Dosen di FEB Manajemen 2018, menyatakan bahwa sebanyak 92 persen menyatakan baik, sedangkan sisanya sebanyak 7 persen menyatakan sangat baik

Rekapitulasi hasil penilaian mahasiswa terhadap kinerja dosen menunjukkan hasil yang bervariasi mulai dari kategori cukup hingga sangat baik. Secara rata-rata hasil penilaian mahasiswa terhadap kinerja dosen tergolong baik dengan skor ratarata sebesar 4. Hasil ini menunjukkan bahawa rata-rata dosen Jurusan manajemen telah memenuhi semua unsur penilaian dalam melaksanakan tugas mengajar sesuai dengan standar yang telah ditentukan. 


\section{Pelacakan Terhadap Keberadaan Alumni FEB Manajemen Unram Alumni FEB Unram tahun 2017}

Jumlah alumni jurusan manajemen pada FB Unram tahun 2017 sebanyak 304 orang dengan respon rate terdapat pada Tabel berikut.

Tabel 10. Statistik Respon Tracer Sudy Unram Tahun 2019 Lulusan tahun 2017

\begin{tabular}{|l|c|}
\hline \multicolumn{1}{|c|}{ Kriteria } & Jumlah \\
\hline FEB Universitas Mataram & 304 \\
\hline Gross responden tahun 2017 (orang) & 150 \\
\hline Undelivered (orang) & 154 \\
\hline Net responden (orang) & \\
\hline (total-undelivered) & 81 \\
\hline Responden mengisi (orang) & 26.64 \\
\hline Gross Response Rate (persen) & 52.60 \\
\hline Nett Response Rate (persen) & \\
\hline
\end{tabular}

Sejak bulan Mei 2019 sampai dengan Oktober 2019 diperoleh responden mengisi kuesioner sebanyak 81 orang dari 304 lulusan tahun 2017, sementara yang tidadk diketahui kerberadaannya sebanyak 150 orang, karena berbagai alasan (tidak terdapat alamat, telpon tidak dipakai lagi, email tidak dipakai dll)

Dari kondisi tersebut diperoleh Gross Respon Rate sebesar 26,64 persen dan Net Response Rater sebesar 52,60 persen.

\section{Metode Pembelajaran oleh Dosen Berdasarkan Penilaian Alumni}

Salah satu tujuan Tracer Study adalah memperoleh feedback dari alumni tentang proses belajar yang dilaksanakan. Pada Tabel 10 berikut disampaikan tanggapan para alumni terhadap proses pembelajaran di Jurusan Manajemen Fakultas Ekonomi dan Bisnis Universitas Mataram.

Tabel 11. Metode Pembelajaran di rusan Manajemen Fakultas Ekonomi dan Bisnis Universitas Mataram

\begin{tabular}{|c|c|c|c|c|c|c|c|c|c|}
\hline \multicolumn{2}{|l|}{ Keterangan } & $\begin{array}{c}\text { [1] Sangat } \\
\text { Besar }\end{array}$ & $\begin{array}{c}\text { [2] } \\
\text { Besar }\end{array}$ & $\begin{array}{l}\text { [3] Cukup } \\
\text { Besar }\end{array}$ & $\begin{array}{c}\text { [4] } \\
\text { Kurang }\end{array}$ & $\begin{array}{l}\text { [5] Tidak } \\
\text { Sama } \\
\text { Sekali }\end{array}$ & jumlah & Rata & Keterangan \\
\hline \multirow{2}{*}{ Perkuliahan } & Nilai & 33 & 34 & 10 & 3 & 1 & 81 & 1.83 & \multirow[b]{2}{*}{ Sangat besar } \\
\hline & Persen & 40.74 & 41.98 & 12.35 & 3.70 & 1.23 & 100 & & \\
\hline \multirow{2}{*}{ Demonstrasi } & Nilai & 7 & 15 & 11 & 25 & 23 & 81 & 3.52 & \multirow{2}{*}{$\begin{array}{c}\text { Tidak/jarang } \\
\text { sekali }\end{array}$} \\
\hline & Persen & 8.64 & 18.52 & 13.58 & 30.86 & 28.40 & 100 & & \\
\hline \multirow{2}{*}{$\begin{array}{c}\text { Partisipasi dalam proyek } \\
\text { riset }\end{array}$} & Nilai & 8 & 15 & 14 & 14 & 30 & 81 & 3.53 & \multirow{2}{*}{$\begin{array}{c}\text { Tidak/jarang } \\
\text { sekali }\end{array}$} \\
\hline & Persen & 9.88 & 18.52 & 17.28 & 17.28 & 37.04 & 100 & & \\
\hline \multirow{2}{*}{ Magang } & Nilai & 4 & 17 & 7 & 11 & 42 & 81 & 3.86 & \multirow{2}{*}{$\begin{array}{c}\text { Tidak/jarang } \\
\text { sekali }\end{array}$} \\
\hline & Persen & 4.94 & 20.99 & 8.64 & 13.58 & 51.85 & 100 & & \\
\hline \multirow{2}{*}{ Praktikum } & Nilai & 5 & 15 & 22 & 23 & 16 & 81 & 3.37 & \multirow[b]{2}{*}{ Cukup Besar } \\
\hline & Persen & 6.17 & 18.52 & 27.16 & 28.40 & 19.75 & 100 & & \\
\hline \multirow{2}{*}{ Kerja Lapangan } & Nilai & 12 & 15 & 24 & 26 & 4 & 81 & 2.94 & \multirow[b]{2}{*}{ Cukup besar } \\
\hline & Persen & 14.81 & 18.52 & 29.63 & 32.10 & 4.94 & 100 & & \\
\hline \multirow{2}{*}{ Diskusi } & Nilai & 32 & 32 & 17 & 0 & 0 & 81 & 1.81 & \multirow[b]{2}{*}{ Sangat besar } \\
\hline & Persen & 39.51 & 39.51 & 20.99 & - & - & 100 & & \\
\hline
\end{tabular}

Sumber: Data Primer

186 | Pengaruh Brand Ambassador Terhadap Citra Merek dan Keputusan ... 
Data pada Tabel 10 diatas menunjukkan bahwa responden/alumni menilai metode pembelajaran di FEB Unram yang dilakukan dengan perkuliahan sebanyak 33 orang atau 40,74 persen menyatakan sangat tinggi/besar, sebanyak 41,98 persen menyatakan besar dan sisanya menyatakan cukup, kurang bahkan tidak sama sekali. Tabel yang sama menunjukkan bahwa responden/alumni menilai metode pembelajaran dengan metode magang menyatakan tidak samasekali sebanyak 51,85 persen.

Berdasarkan persentase penilaian oleh responden bahwa Metode pembelajaran Diskusi merupakan metode pembelajaran dengan kriteria yang baik dengan persepsi cukup besar/tinggi sebanyak 20,99 persen, 39,51 persen tinggi/besar dan 39,51 menytakan sangat tinggi/besar.

\section{Sumber Biaya Kuliah}

Sumber biaya perkuliahan bagi mahasiswa Jurusan Manajemen FEB Unram umumnya berasal dari orang tua. Namun tidak sedikit dari mahasiswa ini yang mampu memanfaatkan beasiswa yang tersedia di Universitas ataupun melalui instansi lainnya

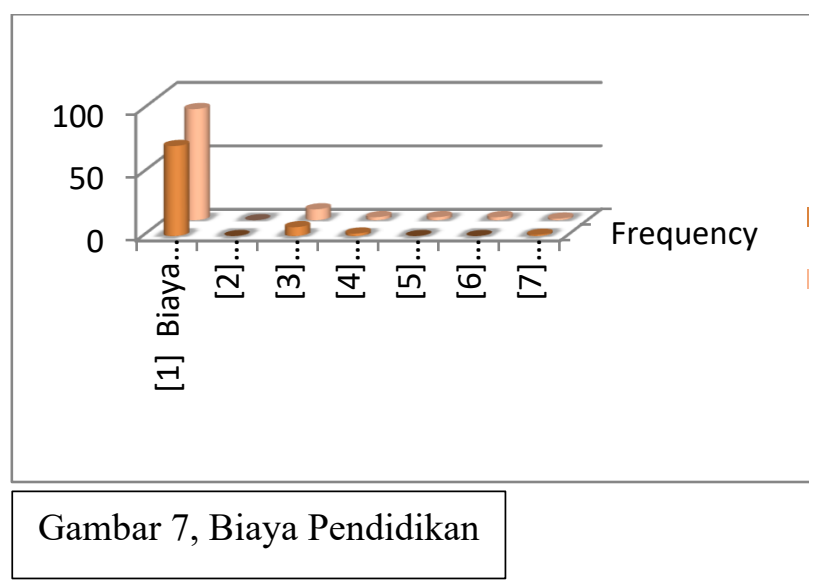

Tabel 11 : Sumber Biaya Pendidikan

\begin{tabular}{|l|r|r|}
\hline \multicolumn{1}{|c|}{ Keterangan } & Freq. & Percent \\
\hline [1] Biaya Sendiri / & 71 & 87.7 \\
Keluarga & 7 & 8.6 \\
3 Beasiswa Bidikmisi & 2 & 2.5 \\
4. Beasiswa PPA & 1 & 1.2 \\
7. Lainnya & 81 & 100.0 \\
Total &
\end{tabular}

Sumber data: data primer

Alumni Jurusan Manajemen FEB Unram lulusan 2017 selama menjalani perkuliahan tercatat bahwa sebanyak 87 persen sumber pembiayaan kuliah mereka berasal dari orang tua. Sementara alumni yang membiayai kuliahnya dari beasiswa ada sekitar 7\%. Sedangkan alumni Jurusan Manajemen FEB Unram lulusan 2017 yang pembiayaan kuliahnya bersumber dari biaya sendiri sebanyak $5 \%$.

\section{Cara Alumni Mencari Pekerjaan}

Salah satu proses yang harus dihadapi oleh alumni adalah periode peralihan dari 
dunia pendidikan menuju duna kerja yang mana alumni bersaing dengan alumni lainya untuk mendapatkan pekerjaan sebagaimana dsajikan dalam tabel berikut:

Tabel 12. Sumber informasi mendapatkan Pekerjaan Alumni FEB Unram Alumni 2017 pada Evaluasi tahun 2019

\begin{tabular}{|r|l|r|r|}
\hline \multicolumn{1}{|c|}{ No. } & \multicolumn{1}{|c|}{ Sumber informasi mendapatkan Pekerjaan } & Jumlah & Persen \\
\hline 1 & Melalui iklan di koran/majalah, brosur & 5 & 7.58 \\
\hline 2 & Melamar ke perusahaan tanpa mengetahui lowongan yang ada & 9 & 13.64 \\
\hline 3 & Pergi ke bursa/pameran kerja & 8 & 12.12 \\
\hline 4 & Mencari lewat internet/iklan online/milis & 20 & 30.30 \\
\hline 5 & $\begin{array}{l}\text { Memeroleh informasi dari pusat/kantor pengembangan karir } \\
\text { fakultas/universitas }\end{array}$ & 1 & 1.52 \\
\hline 6 & Membangun jejaring (network) sejak masih kuliah & 3 & 4.55 \\
\hline 7 & Melalui relasi (misalnya dosen, orang tua, saudara, teman, dll.) & 18 & 27.27 \\
\hline 8 & Membangun bisnis sendiri & 2 & 3.03 \\
\hline & & 66 & \\
\hline
\end{tabular}

Sumber data: data primer

[12] Membangun bisnis sendiri

[11] Melalui relasi (misalnya dosen, orang tua, saudara, teman, dll.)

[10] Membangun jejaring (network) sejak masih kuliah

[8] Memeroleh informasi dari pusat/kantor pengembangan karir fakultas/universitas

[4] Mencari lewat internet/iklan online/milis

[3] Pergi ke bursa/pameran kerja

[2] Melamar ke perusahaan tanpa mengetahui lowongan yang ada

[1] Melalui iklan di koran/majalah, brosur

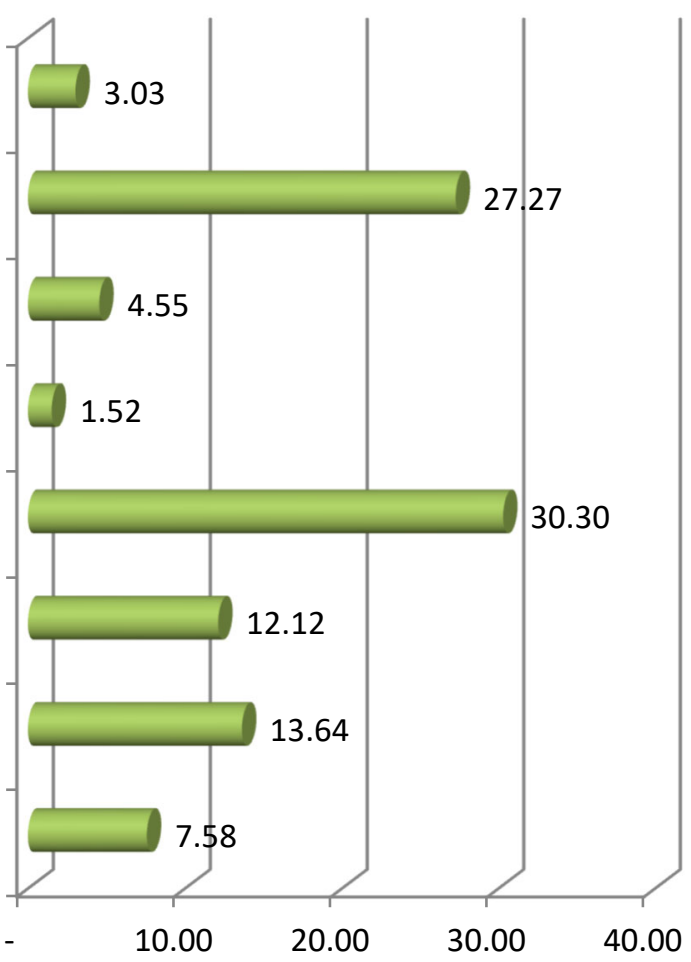

Gambar 8, Perkembangan Pekerjaan Alumni

Ikatan alumni di setiap program studi merupakan aspek penting di dalam memperkuat relasi antar mahasiswa dan alumni khususnya dalam membantu menginformasikan lowongan pekerjaan, sehingga harapannya mahasiswa dengan kontribusi dari alumni dapat memperoleh pekerjaan dengan lebih cepat dan lebih mudah. 


\section{Periode Alumni Mencari dan Mendapatkan Pekerjaan}

Dalam masa tunggu lulusan dalam mencari kerja hingga mendapatkan pekerjaan pertamanya dibagi menjadi dua kelompok yaitu pada periode sebelum dan sesudah lulus. Berikut ini adalah gambaran waktu mulai mencari kerja, dan rata-rata waktu yang dibutuhkan oleh alumni dalam mendapatkan pekerjaan pertamanya

\begin{tabular}{|c|c|c|}
\hline Keterangan & Nilai & Persentase \\
\hline Sebelum lulus & 31 & 38.27 \\
\hline Sesudah lulus & 36 & 44.44 \\
\hline Tidak mencari & 14 & 17.28 \\
\hline Jumlah & 81 & 100 \\
\hline
\end{tabular}

Sumber data : Data primer

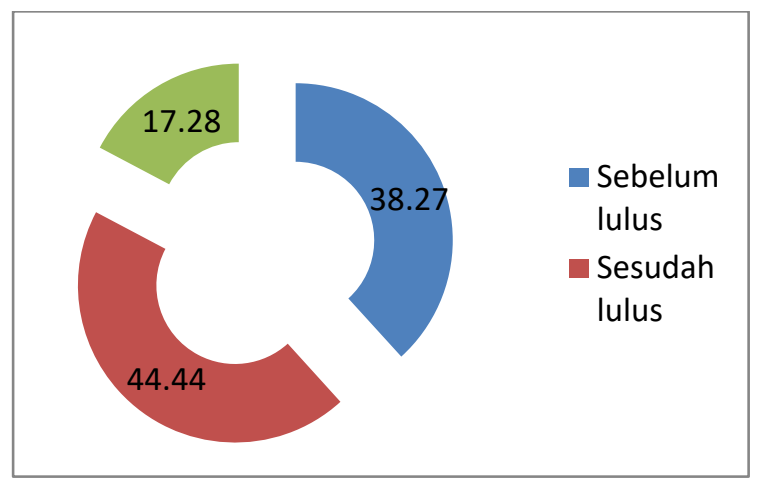

Gambar 9, Lama Mendapat Kerja

Data pada tabel 4.13 diatas menunjukkan bahwa periode mulai mencari pekerjaan alumni FEB Unram jurusan Manajemen ada yang memulai mencari pekerjaan sebelum lulus yaitu sebanyak 38,27 persen da nada yang mencari sesudah lulus sebanyak 44,44 persen. Bahkan ada yang tidak mencari pekerjaan.

Dari proses mencari pekerjaan tersebut para alumni mendapatkan pekerjaan juga ada yang sebelum lulus dan ada yang mendapatkan pekerjaan setelah lulus. tabel 4.14 berikut menunjukkan para alumni yang mendapatkan pekerjaan sebelum dan sesudah lulus.

Tabel 14: Waktu Mulai Mendapatkan dan Rata-rata Waktu Tunggu

Mendapatkan Pekerjaan Pertama Alumni FEB Unram tahun 2019

\begin{tabular}{|r|l|r|r|r|}
\hline No. & \multicolumn{1}{|c|}{ Mendapat Pekerjaan } & Frekuensi & Persen & \multicolumn{2}{|c|}{$\begin{array}{c}\text { Rata-rata Lama } \\
\text { mendapatkan } \\
\text { pekerjaan (bulan) }\end{array}$} \\
\hline 1 & Sebelum lulus & 19 & 23.46 & 3,58 \\
\hline 2 & Setelah lulus & 62 & 76.54 & 4,58 \\
\hline
\end{tabular}

Sumber data : data primer

Data pada Tabel 14 menunjukkan bahwa untuk mendapatkan pekerjaan pertama para alumni mulai mengirim surat lamaran sebelum lulus sebanyak 19 orang atau sebesar 23,46 persen dan rata-rata waktu tunggu mendapatkan pekerjaan selama 3,58 bulan. Disamping itu para alumni mengirim surat lamaran setelah lulus sebanyak 62 orang atau sebesar 76,54 persen dengan rata-rata waktu tunggu selama 4,58 bulan. 


\section{Jumlah Perusahaan Tempat Melamar, Merespon dan memanggil Wawancara Alumni FEB Unram.}

Dalam mendapatkan pekerjaan tersebut para alumni mengirim surat lamaran ke beberapa instansi/perusahaan, dan dari pengiriman tersebut tidak semua instansi/ perusahaan tempat melamar merespon dan memanggil untuk wawancara, hal tersebut dapat dilihat pada Tabel 15 sebagai berikut:

Tabel 15 Jumlah Perusahaan Tempat

Melamar, Merespon dan memanggil Wawancara Alumni FEB Unram

\begin{tabular}{|r|l|c|}
\hline No & \multicolumn{1}{|c|}{ Keterangan } & $\begin{array}{r}\text { Rata-rata Jumlah } \\
\text { Perusahaan/instan } \\
\text { si }\end{array}$ \\
\hline 1 & Tempat melamar & 7.28 \\
\hline 2 & Merespon & 4.04 \\
\hline 3 & $\begin{array}{l}\text { Memanggil } \\
\text { wawancara }\end{array}$ \\
\hline
\end{tabular}

Sumber data : data primer

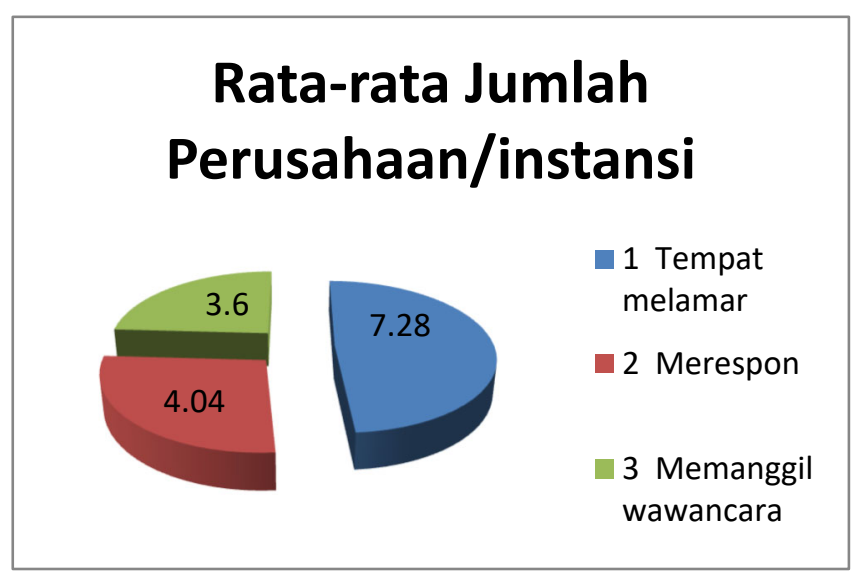

Gambar 10, Jumlah Perusahaan

Informasai data pada Tabel 15 diatas menunjukkan bahwa jumlah lamaran tidak berbanding dengan jumlah yang merespon maupun yang mewawancara. Data diatas menunjukkan bahwa dari rata-rata 7,28 instansi/perusahaan tempat melamar ada 4 perusahaan yang merespon lamarannya dan rata-rata 3,6 perusahaan yang memanggil untuk wawancara.

Untuk mendapatkan gambaran keadaan kerja para aluni, pada Tabel 16 disajikan kondisi kerja para alumni FEB Unram sebagai berikut:

Tabel 16. Status Kerjaan Alumni FEB Unram Sekarang

\begin{tabular}{|r|l|r|r|}
\hline No. & \multicolumn{1}{|c|}{$\begin{array}{c}\text { Mendapat } \\
\text { Pekerjaan }\end{array}$} & Frek. & Persen \\
\hline 1 & Bekerja & 69 & 74.07 \\
\hline 2 & Tidak Bekerja & 12 & 25.93 \\
\hline \multicolumn{2}{|c|}{ Jumlah } & 81 & 100.00 \\
\hline
\end{tabular}

Sumber data : data primer

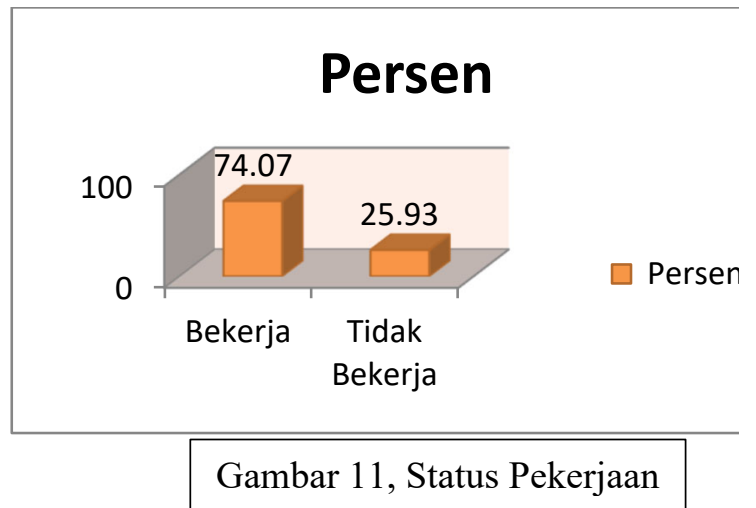

Perser

Tabel 16 diatas menunjukkan bahwa 74 persen atau sebanyak 69 orang para alumni status bekerja dan selebihnya yaitu 25,93 persen tidak bekerja alias masih menganggur.

Untuk mengetahui tempat para alumni bekerja pada tabel 4.17 berikut disajikan jenis perusahaan/instansi tempat alumni bekerja: 
Tabel 17. Jenis Perusahaan/Instansi/Institusi Tempat Anda Bekerja Sekarang (f11)

\begin{tabular}{|c|c|c|c|c|}
\hline Keterangan & Frek. & Percent & $\begin{array}{c}\text { Valid } \\
\text { Percent }\end{array}$ & $\begin{array}{c}\text { Cumulativ } \\
\text { e Percent }\end{array}$ \\
\hline Valid .00 & 3 & 3.7 & 4.2 & 4.2 \\
\hline $\begin{array}{l}\text { [1] Instansi pemerintah (termasuk } \\
\text { BUMN) }\end{array}$ & 13 & 16.0 & 18.1 & 22.2 \\
\hline $\begin{array}{l}\text { [2] Organisasi non-profit/Lembaga } \\
\text { Swadaya Masyarakat }\end{array}$ & 4 & 4.9 & 5.6 & 27.8 \\
\hline [3] Perusahaan swasta & 47 & 58.0 & 65.3 & 93.1 \\
\hline [4] Wiraswasta/perusahaan sendiri & 3 & 3.7 & 4.2 & 97.2 \\
\hline [5] Lainnya, tuliskan: & 2 & 2.5 & 2.8 & 100.0 \\
\hline Total & 72 & 88.9 & 100.0 & \\
\hline Missing System & 9 & 11.1 & & \\
\hline Total & 81 & 100.0 & & \\
\hline
\end{tabular}

Surmber data : data primer

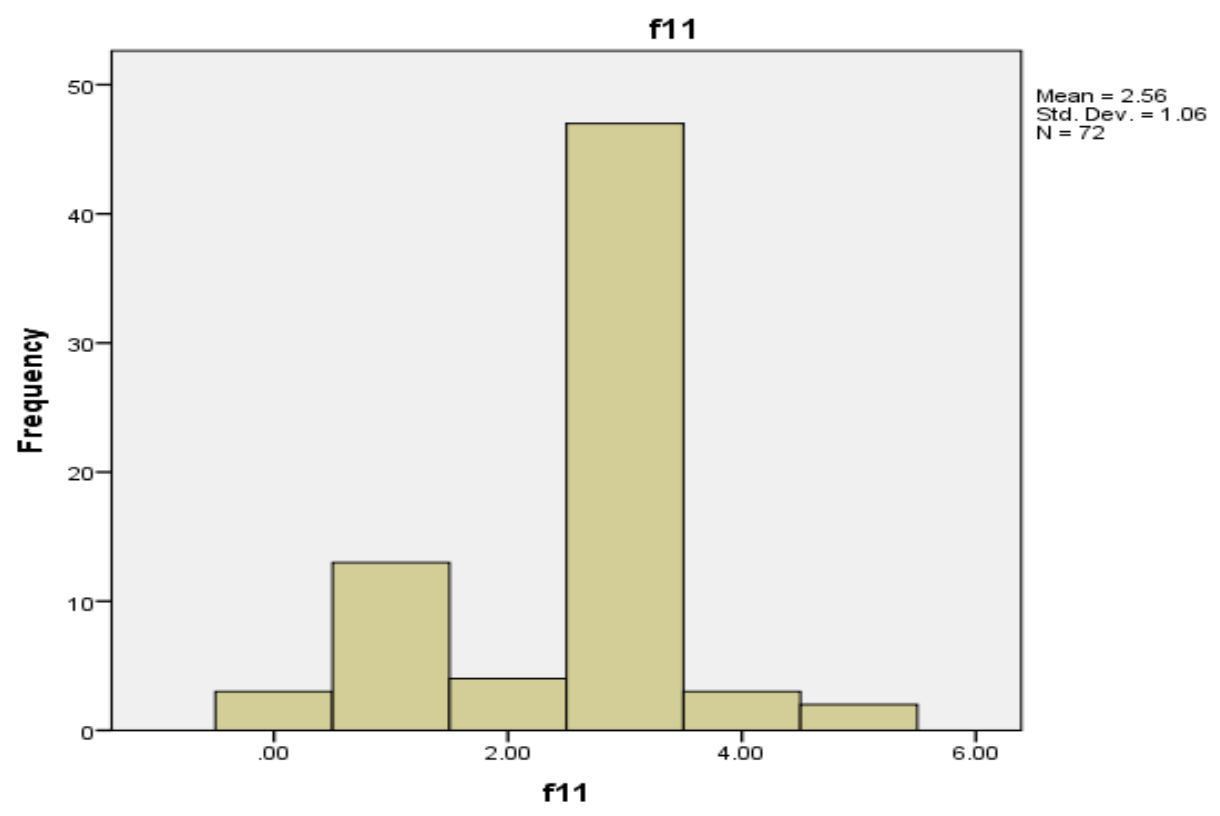

Gambar 12. Jenis Perusahaan/Instansi/Institusi Tempat Anda Bekerja Sekarang

Tabel 17 menunjukkan bahwa sebanyak 58 persen lulusan bekerja di perusahaan swasta, kemudian di instansi pemerintah (termasuk BUMN) sebanyak 16 persen, sedangkan sisanya di lain-lain dan organisasi non profi.

\section{Besanya gaji yang diterima}

Berdasarkan data gambar di atas, rerata gaji minimum yang didapat oleh lulusan FEB Unram adalah rata-rata sebesar Rp. 2.660.300,- per bulan.

Tabel 18 Total Pendapatan perbulan Alumni 2017 FEB Unram

\begin{tabular}{|c|c|c|c|}
\hline No. & Pendapatan & Jumlah & Persentase \\
\hline 1 & $<1.000 .000$ & 2 & 2.90 \\
\hline 2 & $1.000 .000-2.900 .000$ & 35 & 50.72 \\
\hline 3 & $3.000 .000-4.900 .000$ & 22 & 31.88 \\
\hline 4 & $5.000 .000<$ & 10 & 14.49 \\
\hline \multicolumn{2}{|r|}{ Jumlah } & 69 & 100 \\
\hline
\end{tabular}

Sumber data: Data primer 
Data pada tabel 4.18 diatas menunjukkan bahwa jumlah alumni yang berpendapatan pada kisaran rata-rata golongan $\mathrm{Rp} 1.000 .000-\mathrm{Rp} 2.900 .000$ yang paling banyak yaitu sebanyak 50,72 persen atau sebanyak 35 orang, yang lainnya 2, 9 persen berada dibawah Rp 1.000.000,- dan 32 persen berada diatas $\mathrm{Rp} 3.000 .000$,-

\section{Keselarasan Horizontal}

Keselarasan Horizontal merupakan keselarasan antara bidang ilmu yang ditekuni dengan bidang pekerjaan yang ditangani. Hasil data alumni FEB jurusan Manajemen Unram menunjukkan bahwa bidang pekerjaan yang ditekuni sangat sesuai dengan bidang ilmu yang kuasai.

Tabel 19. Keselarasan Horizontal (Keerat hubungan antara bidang studi dengan pekerjaan)

\begin{tabular}{|l|l|r|r|r|r|}
\hline \multicolumn{2}{|c|}{} & Frek. & Percent & Valid Percent & $\begin{array}{c}\text { Cumulative } \\
\text { Percent }\end{array}$ \\
\hline \multirow{4}{*}{ Valid } & .00 & 2 & 2.5 & 2.8 & 2.8 \\
\cline { 2 - 6 } & {$[1]$ Sangat Erat } & 16 & 19.8 & 22.2 & 25.0 \\
\cline { 2 - 6 } & {$[2]$ Erat } & 25 & 30.9 & 34.7 & 59.7 \\
\cline { 2 - 6 } & {$[3]$ Cukup Erat } & 17 & 21.0 & 23.6 & 83.3 \\
\cline { 2 - 6 } & {$[4]$ Kurang Erat } & 4 & 9.9 & 11.1 & 94.4 \\
\cline { 2 - 7 } & [5] Tidak Sama Sekali & 72 & 88.9 & 5.6 & 100.0 \\
\cline { 2 - 6 } & Total & 9 & 11.1 & & \\
\hline Missing System & 81 & 100.0 & & \\
\hline \multicolumn{2}{|l|}{ Total } & & & & \\
\hline
\end{tabular}

Sumber data: data primer

Grafik: Keselarasan Horizontal

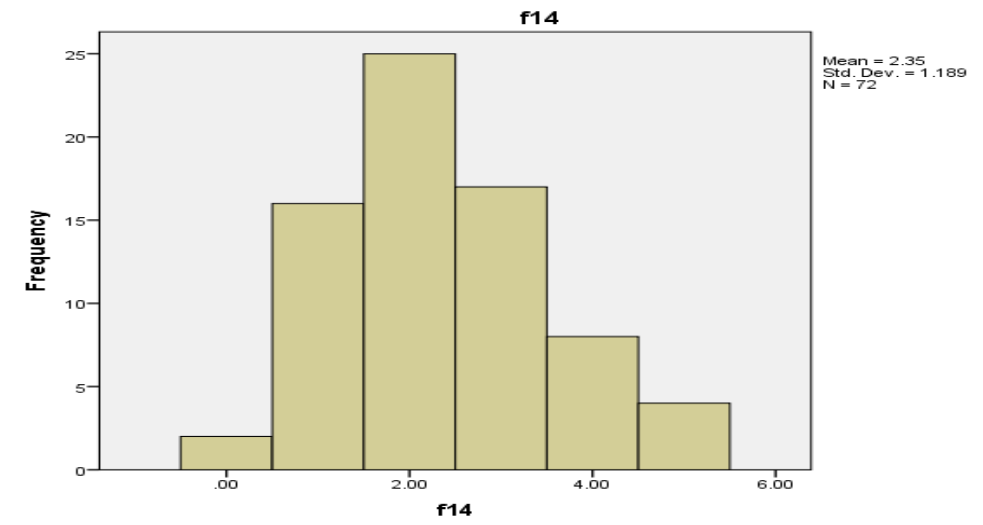

Gambar 13, Keselarasan Horizontal

Berdasarkan grafik di atas, menurut lulusan tingkat kesesuaian kompetensi ilmu yang diperoleh selama pendidikan dirasa sudah sangat sesuai/erat, erat dan cukup erat dengan pekerjaan yang dilakukan yaitu masing-masing 19,80 persen, 30,9 persen, dan 21 persen. Sedangkan yang menyatakan kurang erat dan tidak erat masing-masing 9,9 persen dan 4,9 persen yang merupakan minoritas yang menjawab kesesuaian pekerjaan dengan kompetensi ilmu.

\section{Keselarasan Vertikal}

Keselarasan vertical merupakan kecocokan level/strata pendidikan dengan strata pekerjaan yang ditangani. 
Tabel 20. Tingkat Pendidikan yang Paling Tepat/Sesuai Untuk Pekerjaan Saat Ini

\begin{tabular}{|c|c|c|c|c|c|}
\hline \multicolumn{2}{|r|}{ Keterangan } & Freq & Percent & $\begin{array}{c}\text { Valid } \\
\text { Percent }\end{array}$ & $\begin{array}{c}\text { Cumulative } \\
\text { Percent }\end{array}$ \\
\hline \multirow[t]{6}{*}{ Valid } & .00 & 2 & 2.5 & 2.8 & 2.8 \\
\hline & 1. Setingkat Lebih Tinggi & 3 & 3.7 & 4.2 & 6.9 \\
\hline & 2. Tingkat yang Sama & 52 & 64.2 & 72.2 & 79.2 \\
\hline & 3. Setingkat Lebih Rendah. & 12 & 14.8 & 16.7 & 95.8 \\
\hline & 4. Tidak Perlu Pendidikan Tinggi & 3 & 3.7 & 4.2 & 100.0 \\
\hline & Total & 72 & 88.9 & 100.0 & \\
\hline \begin{tabular}{|l|} 
Missin \\
$\mathrm{g}$
\end{tabular} & System & 9 & 11.1 & & \\
\hline \multicolumn{2}{|l|}{ Total } & 81 & 100.0 & & \\
\hline
\end{tabular}

Sumber data : data primer diolah

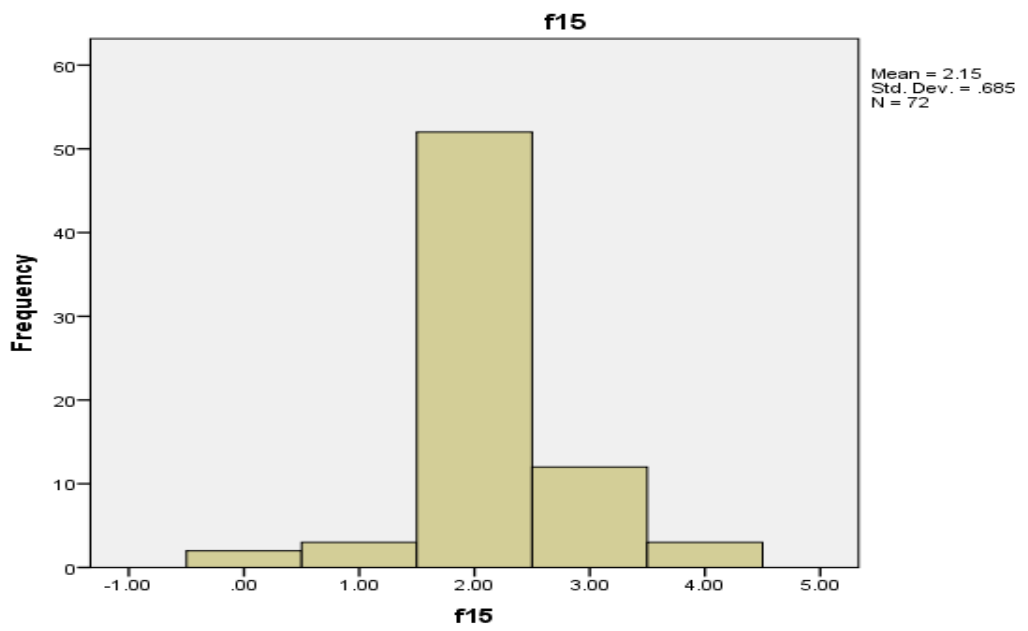

Gambar 14, Keselarasan Vertikal

Tabel 20 menunjukkan bahwa tingkat keselarasan antara bidang pekerjaan dengan level pendidikan pada alumni FEB Unram yang paling banyak adalah melakukan pada level pekerjaan yang sama sebesar 67,2 persen, sedangkansisanya berada pada level yang lebih rendah.

\section{Kompetensi}

Poin-poin penilaian kompetensi alumni yang dijadikan bahan pengukuran antara lain: pengetahuan di bidang ilmu, pengetahuan di luar bidang ilmu, pengetahuan umum, keterampilan internet, keterampilan komputer, berpikir kritis, keterampilan riset, kemampuan belajar, kemampuan berko-munikasi, bekerja di bawah tekanan, manajemen waktu, bekerja secara mandiri, bekerja tim, kemampuan dalam memecahkan masalah, negosiasi, kemampuan analisis, toleransi, kemampuan adaptasi, loyalitas dan integritas, bekerja dengan orang yang berbeda budaya ataupun latar be-lakang, kepemimpinan, tanggung jawab, inisiatif, manajemen proyek/program, menuliskan laporan, merepresentasikan ide, serta kemampuan untuk terus belajar sepanjang hayat.

Kompetensi yang dimiliki alumni pada saat lulus dan kompetensi yang dibutuhkan dunia kerja. 


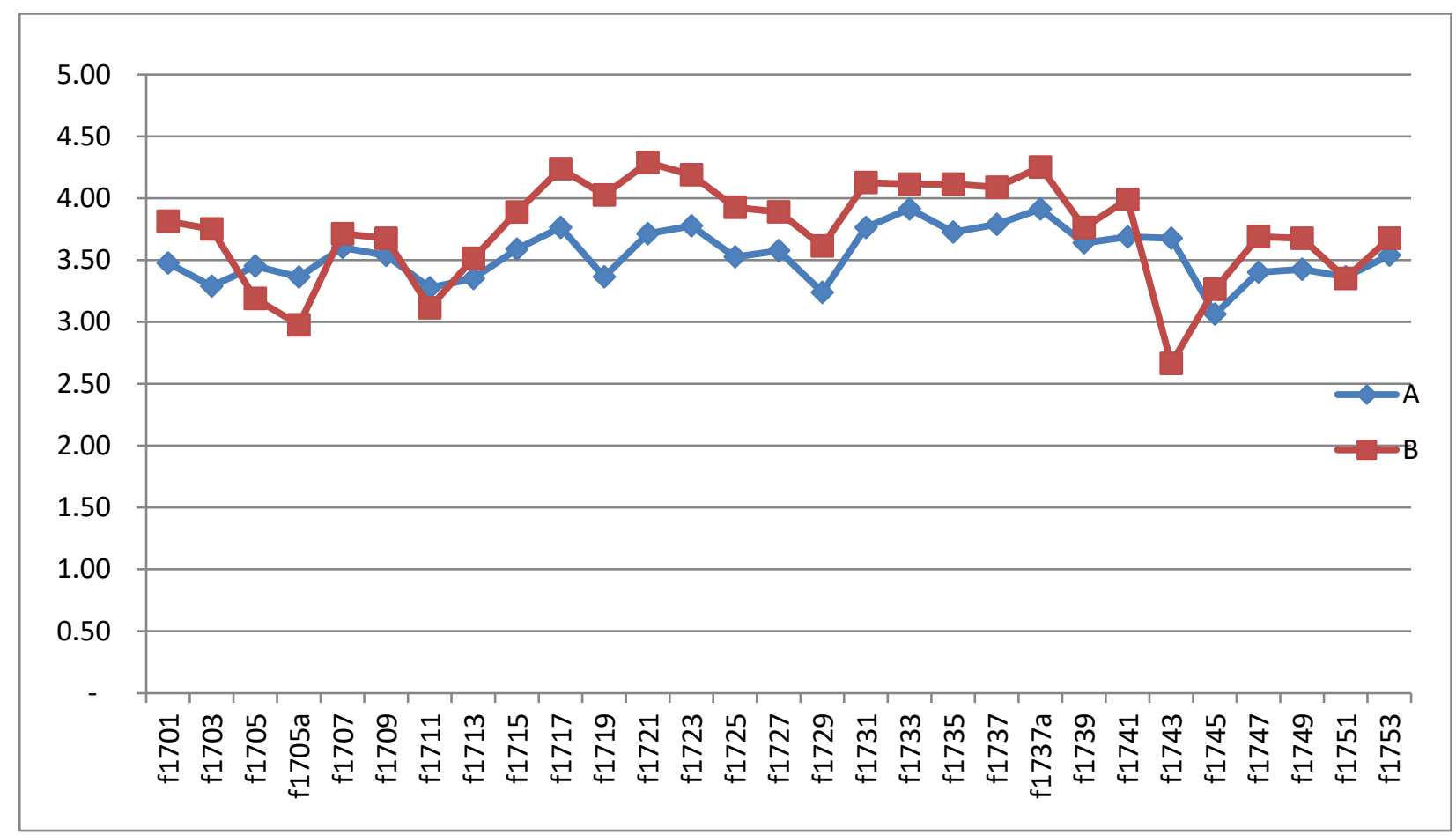

Gambar 15, Kompetensi di Dunia Kerja

\section{KESIMPULAN DAN SARAN}

\section{Kesimpulan}

1) Kompetensi Dosen FEB Jurusan Manajemen ditinjau dari tiga aspek

a. Persentase Dosen yang mendapat tunjangan sertifikasi, dari 60 orang dosen FEB jurusan manajemen sebanyak 58 orang $(96,67 \%)$ telah mendapat tunjangan serifikaasi dosen, sisanya 2 orang $(3,33 \%)$ belum mendapat sertifikasi dosen, ini berarti bahwa sebagian besar telah memenuhi syarat sebagai dosen yang berkompeten.

b. Dari sisi perilaku kerja dosen FEB Manajemen Unram, sebanyak 58 orang atau 95,08 persen berperilaku sangat baik, dan sisanya berperilaku baik

c. Jabatan Fungsional Dosen FEB Manajemen Unram, Jabatan Guru Besar 1 orang (1.64 persen), jabatan Lektor Kepala orang (31.15 persen), jabatan Lektor 32 orang (52.46 persen), jabatan Asisten Ahli 9 orang (14,75 persen) Tingkat Pendidikan Dosen FEB sudah menenuhi ketentuan yang sudah ada, dengan kondisi 38,33 persen (23 orang) sudah berpendidikan S-3, sisanya 61,67 persen (37 orang) berpendidikan S-2.

2) Lama masa tunggu para alumni Manajemen FEB dalam memasuki dunia kerja, 19 orang mendapatkan pekerjaan sebelum lulus $(23,46 \%)$ dengan masa tunggu ratarata,5,8 bln sebelum lulus sedangkan 62 orang $(76,54 \%)$ mendapatkan pekerjaan sessudah lulus dengan masa tunggu rata-rata 4,58 bulan

3) Sebanyak 19,8\% responden menyatakan bahwa antara latar belakang pendidikan dengan pekerjaan pertama yang ditekuni sangat erat, 30,9 persen menyatakan erat, $21 \%$ menyatakan cukup erat, 9,9 persen meyatakan kurang erat dan sisanya 4,9 persen menyatakan tidak sama sekali.

4) Kompetensi Rata-rata alumni yang dikuasai selama mengikuti pendidikan di FEB Unram tinggi dengan nilai sebesar 3,21 dalam rentang 1 sampai 5. dan kontribusi

194 | Pengaruh Brand Ambassador Terhadap Citra Merek dan Keputusan ... 
dari FEB sebesar 3,48

Saran

Berdasarkan hasil penelitian dan kesimpulan maka dapat disarankan sebagai berikut:

1. Agar tenaga dosen sebanyak 2 orang yang belum menedapat sertifikat pendidik segera diurus dan mendapat perhatian.

2. Agar diupayakan percepatan sebanyak 23 orang yang jenjang pendidikannya sudah S3 dan yang termasuk fungsional Lektor kepala menjadi guru besar dengan memfasilitasi untuk menulis artikel masuk ke jurnal internasional

3. Agar tenaga dosen sebanyak 37 orang masih jenjang Pendidikan S2 untuk bisa ditingkatkan pendidikannya ke jenjang S3 dengan memfasilitasi beasiswa baik untuk dalam negeri maupun luar negeri

4. Agar kurikulum pembelajaran selalu disesuaikan dengan kebutuhan lapangan kerja, dengan melibatkan stackholder.

\section{REFERENSI}

Badan Akreditasi Nasional Perguruan Tinggi. 2011. Akreditasi Institusi Perguruan Tinggi Buku III Pedoman Penyusunan Borang. Jakarta (ID): BAN-PT.

Badan Akreditasi Nasional Perguruan Tinggi. 2011. Akreditasi Program Studi Sarjana Buku V Pedoman Penilaian Akreditasi Program Studi Sarjana. Jakarta (ID): BAN-PT.

.Badan Akreditasi Nasional Perguruan Tinggi. 2011. Akreditasi Program Studi Sarjana Buku VI Matriks Penilaian Instrumen Akreditasi Program Studi Sarjana. Jakarta (ID): BAN-PT.

. Institut Pertanian Bogor. 2010. Panduan Program Pendidikan Sarjana Edisi Tahun 2010. Bogor (ID). IPB Press.

Antoinette, Lucia D. and Lepsinger, R. 1999. The Art and Science of Competency Model. San Francisco: Jossey-Bass/Pfeiffer

Amstrong, Michael. 2001. Handbook of Human Resources Management Practice, London and Philadelphia: Kogan Page.

A, Wahyuni D, Supriyanto dan Mulyani E. 2012. Analisis Relevansi Lulusan Perguruan Tinggi dengan Dunia Kerja. Jurnal Economia. 8 (1):

Ansyar \& Nurtain (1993) Pengembangan dan Inovasi Kurikulum. Depdiknas.

Brown, Barry, Dacin and Gunst, 2005, "Spearching for a consensus antecendent role of service quality and satisfaction: an exploratory National Study". Journal of Business Research, Vol. 51. pp. 53-60.

Fuad, Noor dan Ahmad, G. 2009. Integrated Human Resources Development. Jakarta: PT. Grasindo

Hasan Alwi (dkk.). 2002. Kamus Besar Bahasa Indonesia. Jakarta: Balai Pustaka. Edisi Ketiga.

John M. Echols \& Hasan Shadily. 1995. Kamus Inggris - Indonesia: An 
English - Indonesian Dictionary. Jakarta Gramedia. Cetakan 21.

Kotler, Philip. 2002. Manajemen Pemasaran di Indonesia: Analisis, Perencanaan, Implementasi dan Pengendalian. Salemba Empat. Jakarta.

LOMA. 1998. LOMA's Competency Dictionary

Masri Singarimbun \& Sofian Effendi (ed.). 1995. Metode Penelitian Survai. Jakarta: LP3ES. Cetakan 2.

Nasution. 1993. Pengembangan Kurikulum. Bandung: PT. Citra Aditya Bakti. Said Hamid Hasan, 1988, Evaluasi Kurikulum, P2LPTK, Ditjen Dikti, Depdikbud, Jakarta.

Syafik Ahmad, Fikawati Sandra, 2016, Tracer Study Metodologi dan Manajemen, PT. RajaGrafindo Persada, Jakarta.

Sudarwan Danim. 2002. Menjadi Peneliti Kualitatif. Bandung. Cetakan 1

TIM Redaksi KBBI. 2002. Kamus Besar Bahasa Indonesia. Jakarta: Balai Pustaka. Edisi III. Cetakan Kedua. 